\title{
Use of otolith microchemistry to investigate the environmental history of European eel Anguilla anguilla
}

\author{
W. N. Tzeng ${ }^{1, *}$, K. P. Severin ${ }^{2}$, H. Wickström ${ }^{3}$ \\ ${ }^{1}$ Department of Zoology, College of Science, National Taiwan University, Taipei, Taiwan 10617, ROC \\ ${ }^{2}$ Department of Geology and Geophysics, University of Alaska Fairbanks, Alaska 99775-0760, USA \\ ${ }^{3}$ Institute of Freshwater Research, S-178 93 Drottningholm, Sweden
}

\begin{abstract}
Environmental history of the European eel Angulla angulla (L.) collected from Swedish brackish waters and lakes was studied by examining strontium (Sr) and calclum (Ca) in their otoliths with wavelength dispersive $\mathrm{X}$-ray spectrometry on an electron microprobe. The $\mathrm{Sr} / \mathrm{Ca}$ ratios in the otohths changed with both ontogenetic development and salınity of the habitat. A peak $\mathrm{Sr} / \mathrm{Ca}$ ratio of approximately $2 \times 10^{-2}$ was observed in the marine phase of the otoliths, corresponding to the period when a leptocephalus metamorphosed into a glass eel. The ratios decreased to $5.72( \pm 0.32) \times 10^{-3}$ at yellow eel stage when the fish lived in brackish water and to $3.7( \pm 0.20) \times 10^{-4}$ in fresh water. The ratios were significantly different between brackish and fresh water $(p<0.00001)$. Several relatively higher Sr bands were found in otoliths of eel from brackish waters but not in the eels from fresh water. Salinity probably influences Sr deposition more than does temperature or somatic growth rates.
\end{abstract}

KEY WORDS: European eel - Otolith - Strontium/calcium ratios - Elemental X-ray map - Environmental factor Migratory history Electron microprobe

\section{INTRODUCTION}

European eel Anguilla anguilla (L.) is the most abundant of the 18 species of the genus Anguilla in the world. It is widely distributed in fresh water and marine littoral areas of North Africa, the Mediterranean Sea, the British Isles, Iceland, and the western and northern European continent. After spawning in the Sargasso Sea, eel larvae (leptocephali) are transported by the North Equatorial Current, Gulf Stream and North Atlantic Current to the continental shelf of northern European countries. The larvae metamorphose into glass eels in coastal waters. Glass eels become pigmented elvers when they enter estuaries. Some elvers stay in salt or brackish water along the coast while others penetrate rivers and streams to complete the growing stage (yellow eel) in fresh water. Finally, they transform into silver eels and start the downstream migration back to the Sargasso Sea (Bertin 1956, Tesch 1983).

·E-mail: wnt@ccms.ntu.edu.tw
The Baltic Sea is an important growth area for European eel. Elvers reach the Danish Straits, the Sound area between Denmark and Sweden, and the southern part of the Baltic Sea in late spring. The young eels then proceed northwards more slowly but little is known about this gradual dispersal (Svärdson 1976). Commercial catches of silver eels along the coasts of southeastern Sweden and in the outlets of the Baltic Sea have decreased considerably since the mid-1960s (Wickström 1986). This is because the recruitment of elvers entering the Baltic Sea from the Skagerrak and North Sea has been declining steadily for a long period (Erichsen 1976 , Svärdson 1976, Hagström \& Wickström 1990, Westin 1990). As a consequence, stocking programs have been undertaken since the 1940s in the Baltic Sea to try to strengthen the recruitment of elvers and subsequently improve eel stocks (Leopold 1976, Filuk \& Wiktor 1988). For stocking, elvers have been imported from France and the British Isles. Domestic young eels collected on the western coast of Sweden were also restocked in Swedish lakes and the Baltic coast (Wickström 1984). 
Therefore, the eel population in Sweden has a number of different origins. Distinguishing the origin of the eels is important for evaluating the effect of stocking.

Strontium content in the otolith of diadromous fish has been found to differ between fresh water and sea water life history phases (Casselman 1982, Radtke et al. 1988, Kalish 1990, Secor 1992, Otake et al. 1994, Tzeng \& Tsai 1994, Limburg 1995). The difference corresponds to the ambient $\mathrm{Sr}$ concentration which is higher in marine than fresh water (Odum 1957. Tzeng \& Tsai 1994, Tzeng 1995, 1996). Accordingly, Sr content in fish otoliths offers the potential to distinguish between time spent in sea water and fresh water and give information about the fishes' environmental history.

The purpose of this paper is to reconstruct the environmental history of European eels collected from Swedish brackish waters and lakes and to identify the environmental history of eels of unknown origin by examining $\mathrm{Sr}$ and $\mathrm{Ca}$ in their otoliths. The changes in Sr contents in otolith in relation to salinity, temperature and fish growth rate and ontogenetic development are discussed.

\section{MATERIALS AND METHODS}

Sampling design. Twelve otoliths from 5 groups of European eels collected from 3 lakes and 2 brackish water locations in Sweden were used for microchemical analysis (Fig. 1). The origin of Groups 1 through 4 was clear: these eels were captured from areas where the restocking program is well known. The origin of the eels in Group 5 was unknown. The stocking and sampling dates and biological characteristics of the 5 groups of eels (including sampling date, mean ( \pm SD) salinity of sampling sites, sex, developmental stage, age, total length, body weight, and the stage and year at stocking) are given in Table 1. The life history aspects of the 5 groups were as follows:

Group 1: collected from the brackish waters off Strömstad and Björkö on the west coast of Sweden in 1987. This group should have not experienced fresh water life because eels in the western coastal waters are recruited directly from the Atlantic (KattegatSkagerrak) and no stocking has ever been performed there. The eels ranged from 4 to $11 \mathrm{yr}$ old, with the majority between 6 and 9 yr old (Holmgren \& Wickström 1988).

Group 2: collected from the eastern part of Lake Mälaren in 1988 and 1991. The eels were stocked as elvers, which were imported from the Bay of Biscay, France, in the spring of 1980 , and had lived in fresh water for 8 and $11 \mathrm{yr}$, respectively.

Group 3: collected from Lake Ommen in eastern Sweden in 1991. The eels were stocked at the elver stage, having been imported from France in 1979. The eels had lived in fresh water approximately $12 \mathrm{yr}$ (Tzeng et al. 1995)

Group 4: collected from Lake Angen in eastern Sweden in 1991. The eels were stocked at the yellow eel stage after being caught in brackish waters along the west coast of Sweden in 1979. The lake was eelfree before stocking in 1979 (Wickström 1984). It is estimated that the eels lived in the brackish waters and the fresh water lake for approximately 7 and $12 \mathrm{yr}$ respectively (Holmgren \& Wickström 1988).

Group 5: collected in the eastern part of Lake Mälaren in 1994 a few $\mathrm{km}$ away from where Group 2 was collected. The origin of this group was unknown. They were derived either from a natural (wild) population that had migrated from brackish Baltic Sea, or from a stocked population caught from brackish waters on the west coast of Sweden and released at the yellow eel

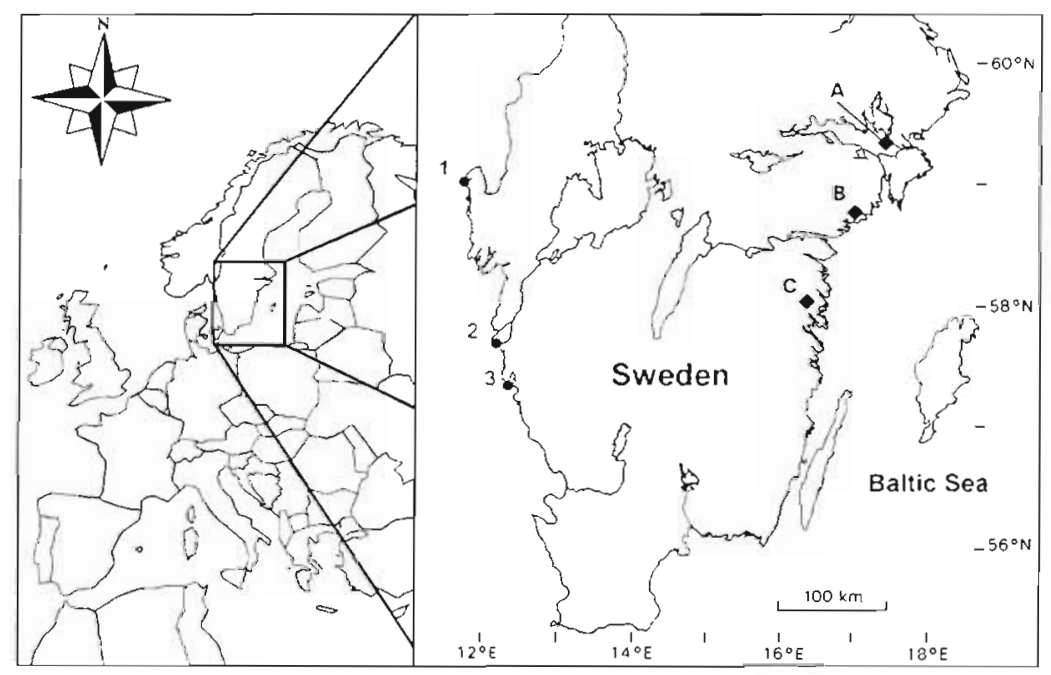

Fig. 1. Map showing the locations where eels were collected from brackish waters along the western coast of Sweden (1, Strömstad; 2 , Björkö) and 3 lakes on the eastern coast (A, Lake Mälaren; B, Lake Ången; C, Lake Ommen). Temperature and salinity were measured in the western coastal waters ( 3 , Kungsbacka) 
Table 1. Life history of the 5 groups of European eels used in this study

\begin{tabular}{|c|c|c|c|c|c|c|c|c|c|c|}
\hline Group & $\begin{array}{l}\text { Specimen } \\
\text { no. }\end{array}$ & $\begin{array}{l}\text { Sampling date } \\
\text { (YY-MM-DD) }\end{array}$ & Samplıng site & $\underset{\substack{\text { Salinity } \\
\left(x_{0}\right)}}{ }$ & Sex & Stage & $\begin{array}{l}\text { Age } \\
(y r)\end{array}$ & $\begin{array}{l}\text { Total length } \\
\text { (mm) }\end{array}$ & $\begin{array}{l}\text { Body weight } \\
\text { (g) }\end{array}$ & $\begin{array}{c}\text { Stage and year } \\
\text { at stocking }\end{array}$ \\
\hline 1 & $\begin{array}{l}11538 \\
11550 \\
11906\end{array}$ & $\begin{array}{l}870709 \\
870709 \\
870820\end{array}$ & $\begin{array}{l}\text { Strömstad (West Coast) } \\
\text { Strömstad (West Coast) } \\
\text { Björkö (West Codst) }\end{array}$ & $\begin{array}{l}25.54 \pm 3.38 \\
25.54 \pm 3.38 \\
23.12 \pm 3.71\end{array}$ & $\begin{array}{l}\varphi \\
\vdots \\
9 \\
9\end{array}$ & $\begin{array}{l}\text { Yellow } \\
\text { Yellow } \\
\text { Yellow }\end{array}$ & $\begin{array}{l}5^{+} \\
7^{+} \\
9^{+}\end{array}$ & $\begin{array}{l}393 \\
410 \\
403\end{array}$ & $\begin{array}{l}96 \\
90 \\
96\end{array}$ & $\begin{array}{l}\text { Natural } \\
\text { Natural } \\
\text { Natural }\end{array}$ \\
\hline 2 & $\begin{array}{l}13743 \\
18589\end{array}$ & $\begin{array}{l}880531 \\
910607\end{array}$ & $\begin{array}{l}\text { Eastern Lake Mälaren } \\
\text { Eastern Lake Mälaren }\end{array}$ & $\begin{array}{l}\text { Fresh water } \\
\text { Fresh water }\end{array}$ & $\begin{array}{l}Q \\
Q\end{array}$ & $\begin{array}{l}\text { Yellow } \\
\text { Yellow }\end{array}$ & $\begin{array}{r}8^{+} \\
11^{+}\end{array}$ & $\begin{array}{l}562 \\
717\end{array}$ & $\begin{array}{l}442 \\
566\end{array}$ & $\begin{array}{l}\text { Elver, } 1980 \\
\text { Elver, } 1980\end{array}$ \\
\hline 3 & $\begin{array}{l}19894 \\
19991\end{array}$ & $\begin{array}{l}910628 \\
910811\end{array}$ & $\begin{array}{l}\text { Lake Ommen } \\
\text { Lake Ommen }\end{array}$ & $\begin{array}{l}\text { Fresh water } \\
\text { Fresh water }\end{array}$ & $\begin{array}{l}9 \\
9\end{array}$ & $\begin{array}{l}\text { Yellow } \\
\text { Yellow }\end{array}$ & $\begin{array}{l}12^{+} \\
12^{+}\end{array}$ & $\begin{array}{l}618 \\
521\end{array}$ & $\begin{array}{l}451 \\
230\end{array}$ & $\begin{array}{l}\text { Elver, } 1979 \\
\text { Elver, } 1979\end{array}$ \\
\hline 4 & $\begin{array}{l}18793 \\
19315\end{array}$ & $\begin{array}{l}910701 \\
910716\end{array}$ & $\begin{array}{l}\text { Lake Angen } \\
\text { Lake Angen }\end{array}$ & $\begin{array}{l}\text { Fresh water } \\
\text { Fresh water }\end{array}$ & $\begin{array}{l}9 \\
9\end{array}$ & $\begin{array}{l}\text { Yellow } \\
\text { Yellow }\end{array}$ & $\begin{array}{l}\geq 14^{\circ} \\
\geq 18^{+}\end{array}$ & $\begin{array}{l}760 \\
728\end{array}$ & $\begin{array}{l}820 \\
668\end{array}$ & $\begin{array}{l}\text { Yellow eel, } 1979 \\
\text { Yellow eel, } 1979\end{array}$ \\
\hline 5 & $\begin{array}{l}25106 \\
25108 \\
25110\end{array}$ & $\begin{array}{l}940830 \\
940830 \\
940830\end{array}$ & $\begin{array}{l}\text { Eastern Lake Mälaren } \\
\text { Eastern Lake Mälaren } \\
\text { Eastern Lake Mälaren }\end{array}$ & $\begin{array}{l}\text { Fresh water } \\
\text { Fresh water } \\
\text { Fresh water }\end{array}$ & $\begin{array}{l}9 \\
9 \\
9\end{array}$ & $\begin{array}{l}\text { Yollow } \\
\text { Yellow } \\
\text { Yellow }\end{array}$ & $\begin{array}{l}13^{+} \\
18^{*} \\
14^{+}\end{array}$ & $\begin{array}{l}723 \\
721 \\
680\end{array}$ & $\begin{array}{l}597 \\
535 \\
461\end{array}$ & $\begin{array}{l}\text { Unknown } \\
\text { Unknown } \\
\text { Unknown }\end{array}$ \\
\hline
\end{tabular}

stage at approximately $40 \mathrm{~cm}$ in total length, or from a stocked population released at the elver stage imported from France or the British Isles (Wickström 1984).

Microchemical analysis. The otoliths removed from the eel were cleaned with distilled water and dried in air. Maximum lengths of the otoliths were measured to the nearest $0.1 \mu \mathrm{m}$ with the aid of an image-processing system (VIPRO 512). Then, the otoliths were embedded in thermo-epoxy (Petropoxy 154, Palouse Petro Products, USA) and cured for 1 h at $135^{\circ} \mathrm{C}$. Embedded otoliths were ground from the proximal side of the sagittal plane of the fish until the primordium of the otolith was revealed. For microprobe analysis, the polished otoliths were coated under vacuum with a $30 \mathrm{~nm}$ layer of carbon to reduce X-ray diffraction and increase electron conductance. The embedding, grinding, and coating procedures were similar to a previous study (Tzeng \& Tsai 1994).

Quantitative measurements and mapping of the concentration of trace elements in otolith of the eel were conducted using an electron microprobe equipped with wavelength dispersive spectrometers (Cameca SX-50). Quantitative measurements of $\mathrm{Na}, \mathrm{Mg}, \mathrm{Cl}, \mathrm{P}, \mathrm{S}, \mathrm{K}, \mathrm{Ca}$, and $\mathrm{Sr}$ were made at approximately $18 \mu \mathrm{m}$ intervals along a transect from the primordium to the edge of the otolith. Of these elements Sr was the best for distinguishing between fresh water and marine environments. For the measurements of Sr and Ca, calcite (USNM136321) and strontianite (NMNH10065) from the Department of Mineral Sciences, National Museum of Natural History, Smithsonian Institution, Washington DC, USA were used as standards for calibration. A $15 \mathrm{kV}, 4 \mathrm{nA}, 15 \mu \mathrm{m}$ diameter beam was used. Counting times were $20 \mathrm{~s}$ (Ca) and $120 \mathrm{~s}(\mathrm{Sr})$. Detection limits were $0.077 \mathrm{wt} \%$ (Ca) and $0.045 \mathrm{wt} \%(\mathrm{Sr})$ calculated using the method described in Williams (1987). The spatial distribution of Sr across each otolith was mapped at an $8 \mu \mathrm{m}$ resolution using a $15 \mathrm{kV}, 100 \mathrm{nA}$ beam. X-rays were collected from each point (pixel) for $0.5 \mathrm{~s}$.

\section{RESULTS}

\section{Seasonal changes in temperature and salinity}

Fig. 2 shows seasonal changes in surface temperature and salinity measured every 10 to $13 \mathrm{~d}$ (except the years $1986-88$ ) in the coastal waters off Kungsbacka on the western coast of Sweden from January 1980 through July 1991. Temperature ranged from -1.6 to $21.1^{\circ} \mathrm{C}$. Salinity ranged 9.74 to $32.78 \%$. Seasonal change of temperature was regular, but not salinity. Salinity became higher when temperature decreased.

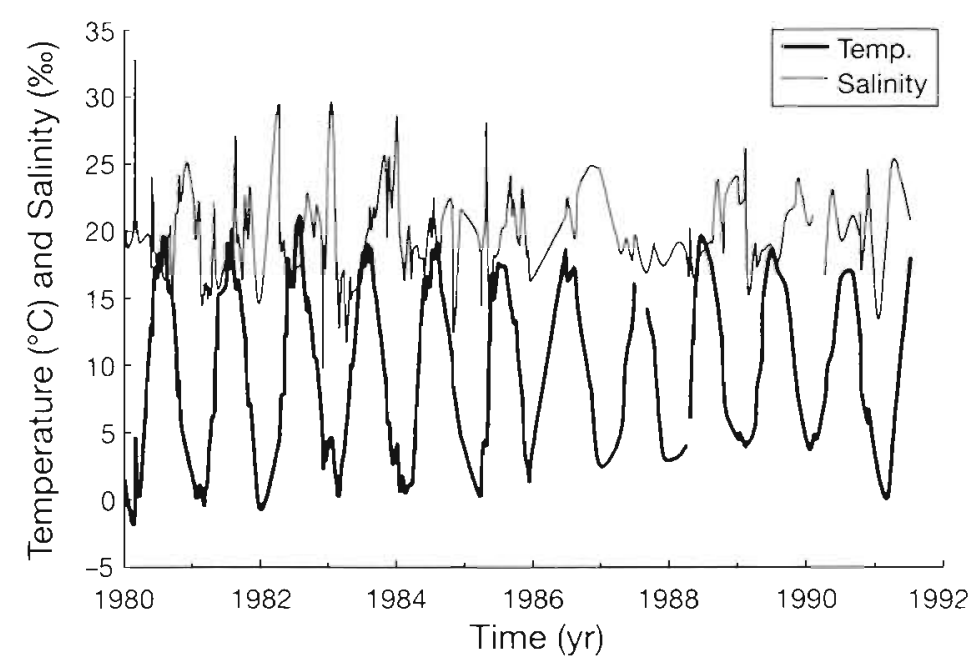

Fig. 2. Seasonal changes in water temperature and salinity in the coastal waters off Kungsbacka in western Sweden from January 1980 to June 1991 

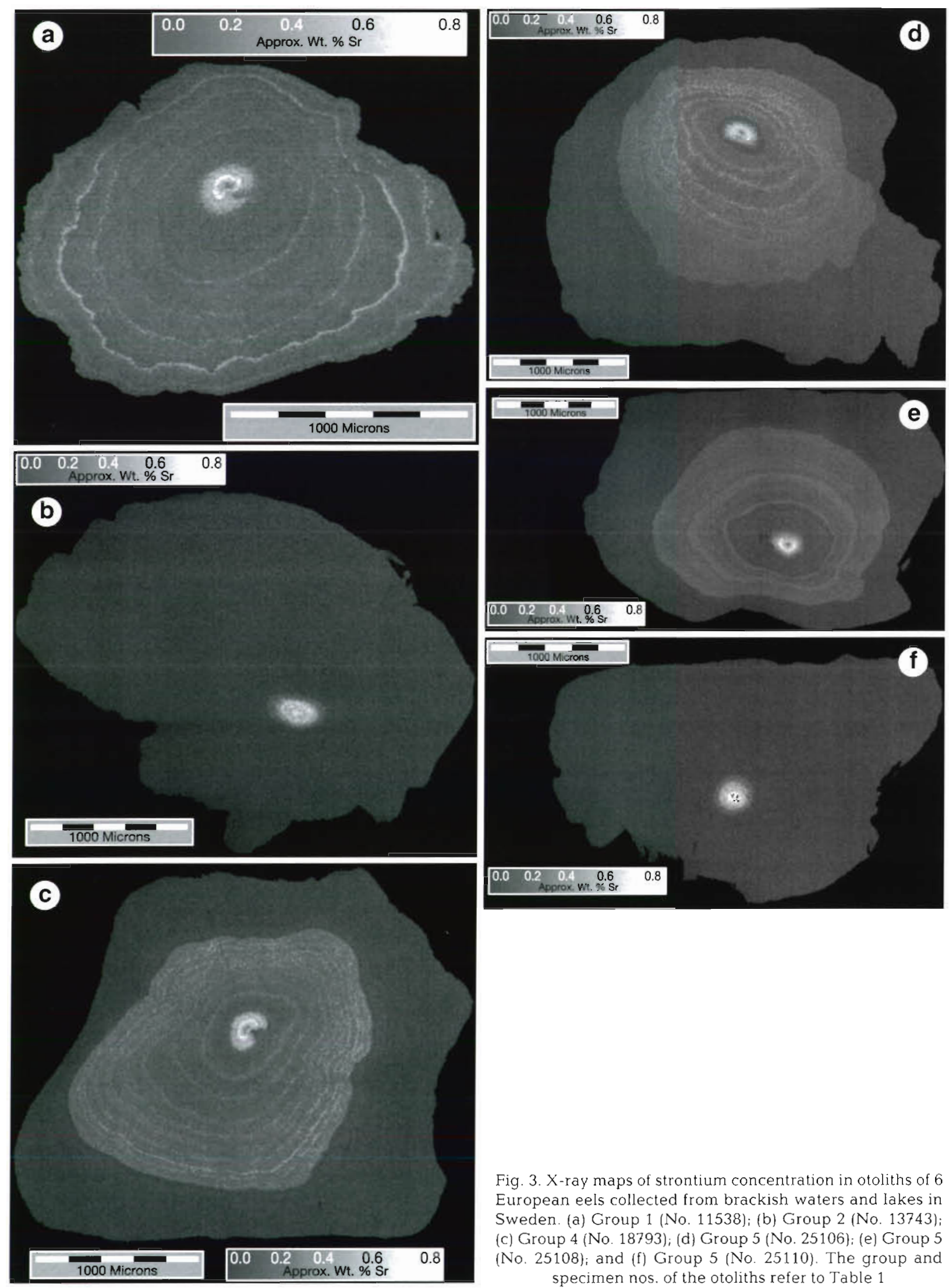

Fig. 3. X-ray maps of strontium concentration in otoliths of 6 European eels collected from brackish waters and lakes in Sweden. (a) Group 1 (No. 11538); (b) Group 2 (No. 13743); (c) Group 4 (No. 18793); (d) Group 5 (No. 25106); (e) Group 5 (No. 25108); and (f) Group 5 (No. 25110). The group and specimen nos. of the otoliths refer to Table 1 


\section{X-ray map of Sr contents in otoliths}

Twelve X-ray maps of Sr contents in otoliths of the 5 groups of European eel were made (Table 1). Six of them are shown in Fig. 3. The brighter areas in the $\mathrm{X}$-ray map indicate higher $\mathrm{Sr}$ concentrations. The bright area of highest Sr content approximately equaled the size of the otolith of an elver, approximately $156.6 \mu \mathrm{m}$ in radius (Tzeng et al. 1995). In other words, the nucleus was deposited during marine life phase while the eel larvae migrated from its spawning ground to the estuary.

Beyond the nucleus the brightness in the $X$-ray images decreased, indicating that the Sr concentrations decreased (Fig. 3). The amount of decrease depended on the salinity content of the habitat where the eel lived after elver stage. Sr content was higher for eels that lived in brackish waters (Fig. 3a, Group 1) than for those from a fresh water environment (Fig. 3b, Group 2). This difference was more obvious in an individual eel which had passed the brackish-fresh water gradient environment (Fig. 3c. Group 4). This suggested that the Sr content pattern in otoliths could be used to reconstruct the history of salinity experienced by the eel.

The origin of Group 5 was unknown (Fig. 3d-f). The pattern of Sr content in otoliths of Nos. 25106 and 25108 (Fig. 3d, e) was similar to that of Group 4 (Fig. 3c), while No. 25110 (Fig. 3f) was similar to that of Group 2 (Fig. 3b).

Furthermore, the X-ray maps of $\mathrm{Sr}$ contents in otoliths for the eels in Groups 1 \& 4, and Nos. 25106 and 25108 in Group 5, revealed several bands of high $\mathrm{Sr}$ content, while no bands of high Sr content were found in the otoliths from Groups 2 and 3.

\section{$\mathrm{Sr} / \mathrm{Ca}$ ratios in otoliths of natural eels from brackish water (Group 1)}

Sr/Ca ratios measured along a transect from the primordium to the otolith edge of the natural eels collected in the coastal waters off Strömstad and
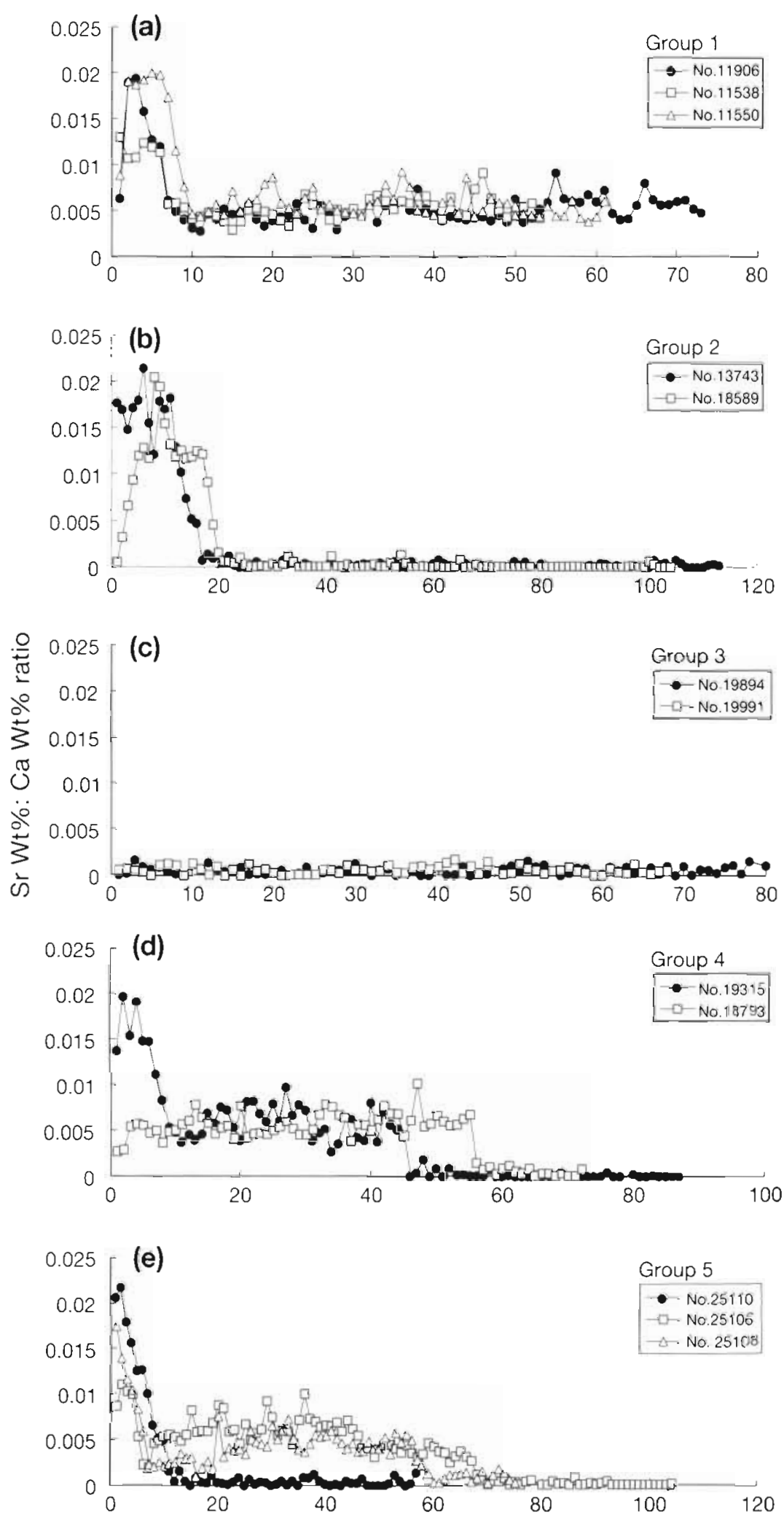

No. of microprobe spots

Fig. 4. Sr/Ca ratios scanned along a transect from the primordium to the edge of otoliths of 12 eels collected from brackish waters and lakes of Sweden. The group and specimen nos. of the otoliths refer to Table 1 
Björkö on the west coast of Sweden are shown in Fig. $4 \mathrm{a}$. The ratios increased from the primordium and reached a peak of approximately $2 \times 10^{-2}$ about $113 \mu \mathrm{m}$ from the primordium, then decreased and maintained a low level of approximately $5.72 \times 10^{-3}$ until the edge. The $\mathrm{Sr} / \mathrm{Ca}$ ratios beyond approximately the first 11 spots showed a periodic fluctuation. The peaks of the fluctuation correspond to the bright bands of the $\mathrm{Sr}$ $X$-ray maps as indicated in Fig $3 a$.

\section{$\mathrm{Sr} / \mathrm{Ca}$ ratios in otoliths of eels stocked in fresh water lakes}

Stocked at elver stage (Groups $2 \& 3$ ). $\mathrm{Sr} / \mathrm{Ca}$ ratios measured along a transect from the primordium to the otolith edge of eels collected from Lake Mälaren (Group 2) and Lake Ommen (Group 3) are shown in Fig. $4 \mathrm{~b}, \mathrm{c}$. The Sr/Ca ratios in the nuclei of the otoliths of Group 2 were similar to those of Group 1 (Fig. 4a). No peak Sr/Ca ratios were found in Group 3 because the otoliths were not ground through the primordium (Fig. 4c). The Sr/Ca ratios were significantly different between fresh water environment (Groups $2 \& 3$ ) and brackish waters (Group 1) (1-way ANOVA, $F_{1.5}=$ $643.85, \mathrm{p}<0.0001$ ). The mean ( $\pm \mathrm{SD}) \mathrm{Sr} / \mathrm{Ca}$ ratio beyond the nuclei of the otoliths in Groups $2 \& 3$ was $3.7( \pm 0.20) \times 10^{-4}$, lower than Group $1[5.72( \pm 0.32) \times$ $\left.10^{-3}\right\}$

Stocked from a brackish water yellow eel (Group 4). $\mathrm{Sr} / \mathrm{Ca}$ ratios measured along a transect from the primordium to the otolith edge of the eels collected from Lake Angen are shown in Fig. 4d. The eels were stocked at the yellow eel stage after being caught from brackish waters on the western coast of Sweden. They had experienced 3 different environments, including a marine phase before the elver stage ( $\mathrm{Sr} / \mathrm{Ca}$ ratio being highest), a brackish water phase ( $\mathrm{Sr} / \mathrm{Ca}$ ratio moderate), and a fresh water phase ( $\mathrm{Sr} / \mathrm{Ca}$ ratio lowest). The pattern of $\mathrm{Sr} / \mathrm{Ca}$ ratios in the Group 4 otoliths is a combination of Group 1 and Groups 2 or 3. This pattern is clearly discernible in Sr X-ray maps (Fig. 3). These indicated that the environmental history of the eels could be distinguished from the time-series changes of the $\mathrm{Sr} / \mathrm{Ca}$ ratios.

\section{$\mathrm{Sr} / \mathrm{Ca}$ ratios in otoliths of eels of unknown origin (Group 5)}

$\mathrm{Sr} / \mathrm{Ca}$ ratios measured along a transect from the primordium to the otolith edge of the 3 unknown-origin eels collected away from Lake Mälaren are shown in Fig. 4e. The pattern of $\mathrm{Sr} / \mathrm{Ca}$ ratios in the first 2 eels (Nos. 25106 and 251.08) was similar to those of Group 4
(No. 19315). The third one (No. 25110) was similar to Group 2. This pattern was clearly discernible in $\mathrm{Sr}$ $X$-ray maps (Fig. 3). This indicated that Nos. 25106 and 25108 experienced 3 different environments, while No. 25110 experienced only 2; i.e. the former lived in brackish waters for a long period before moving to fresh water, while the latter moved to a fresh water environment at elver stage.

\section{DISCUSSION AND CONCLUSION}

\section{Advantage of X-ray map}

The X-ray maps proved to be very useful although they are qualitative. The comparison of $\mathrm{Sr}$ patterns among otoliths is simple in the images, but rather difficult in the data from the transects. Although we attempted to start our transects at the exact nucleus, in some cases the nucleus was not quantitatively analysed. The maps show that all otoliths had a high $\mathrm{Sr}$ area in their centers. In addition, they show that the deposition of $\mathrm{Sr}$ is approximately radially symmetrical. This indicates that the direction chosen for taking a quantitative transect is relatively unimportant and that a transect in any direction will cross all high and low Sr regions. However, the spacing of high and low Sr regions will vary depending on the direction chosen, possibly complicating comparisons among transects.

\section{Peak Sr/Ca ratio in the otolith nucleus}

Regardless of whether the otoliths were removed from natural eels from brackish waters or stocked eels from fresh water lakes, all showed a peak $\mathrm{Sr} / \mathrm{Ca}$ ratio (approximately $2 \times 10^{-2}$ ) in the nucleus at approximately $100 \mu \mathrm{m}$ from primordium. The ratios then decreased and maintained a lower level, approximately $5.72 \times 10^{-3}$, for the eels from brackish waters and $3.7 \times 10^{-4}$ for those from fresh water lakes (Fig. 4). Such peak ratios were previously reported in otoliths of Japanese eel elvers, and were proposed to correspond to the period when the eel metamorphosed from a leptocephalus to a glass eel (Otake et al. 1994, Tzeng \& Tsai 1994). The leptocephalus is known to contain extensive amounts of gelatinous extracellular matrix composed of sulfated glycosaminoglycans (GAG) which drastically decrease during the process of metamorphosis (Pfeiler 1984). GAG has an affinity to alkali earth elements, especially to Sr (Nishizawa 1978). GAG decreases may reduce the absorption of Sr from sea water and result in a drastic decrease of otolith $\mathrm{Sr}$ content and, consequently, Sr/Ca ratios. The 
early life history of European eels is analogous to that of Japanese eels (Schmidt 1925, Bertin 1956, Tesch 1983, Boetius \& Harding 1985, McCleave \& Kleckner 1985, Castonguay 1987, McCleave et al. 1987). They pass through similar developmental stages during their migration from spawning grounds to estuaries. Accordingly, the mechanism of dramatic decrease of $\mathrm{Sr} / \mathrm{Ca}$ ratios in the nuclei of the otoliths of European eel may be similar to that of Japanese eel

\section{Environmental effect on otolith $\mathrm{Sr}$ contents and $\mathrm{Sr} / \mathrm{Ca}$ ratios}

Sr contents (or Sr/Ca ratios) in the otoliths were significantly different between brackish and fresh water (Group 1 vs Groups 2 and 3 in Fig. 4). The difference was also true for the otolith of an individual eel that had both brackish and fresh water life history phases (Group 4 in Figs. 3 \& 4). Salinity was quite different between coastal brackish waters and inland lakes (Table 1). Sr contents in otolith of the fish were positively correlated to ambient salinity (Kalish 1990. Limburg 1995. Tzeng 1996). Thus the difference in $\mathrm{Sr}$ content in otoliths of European eels between brackish and fresh water environments was probably due to salinity effects. A similar phenomenon has been observed in diadromous fishes as the freshwater-marine gradient was traversed, e.g. migrating eels in the St. Lawrence, Canada (Casselman 1982), anadromous and non-anadromous salmonids in Tasmania (Kalish 1990), striped bass in Chesapeake Bay, USA (Secor 1992), and Japanese eel in Taiwan (Tzeng \& Tsai 1994). These studies indicated that salinity was an important factor influencing the $\mathrm{Sr}$ contents or Sr/Ca ratios in otoliths of the fish.

Several narrow bands of high Sr were found in the otoliths of the eels from Groups 1 and 4 (Fig. 3). These bands were deposited while the eels lived in brackish water. We suggest that they were deposited during a period of high salinity (Tzeng 1996) and low temperature, a time when eel growth is slowed (Bruun 1963, Sinha \& Jones 1967, Tzeng et al. 1995). Sr contents (or Sr/Ca ratios) in fish otoliths have been negatively correlated to both temperature (Radtke 1984, 1989, Gauldie et al. 1986, Radtke et al. 1990, Townsend et al 1992) and fish growth rates (Sadovy \& Severin 1992, 1994). All the eels in this study were exposed to periods of low temperature and, presumably, slow growth, whether they had lived in the fresh water lakes (Groups 2 and 3) or in brackish water (Groups 1 and 4). However, only the eels from brackish water had bands of high Sr in their otoliths (Groups 1 and 4, Fig. 3). The fresh water eels from Groups 2 and 3 did not display any high $\mathrm{Sr}$ bands in their otoliths. From this we conclude that salinity is more important in controlling $\mathrm{Sr}$ incorporation into eel otoliths than is temperature or growth rate.

\section{Possible environmental history of group of unknown origin}

Three eels of unknown origin, Nos. 25106, 25108 and 25110, were collected from the eastern part of Lake Mälaren a few $\mathrm{km}$ away from the stocking locality. Their origins were proposed to be from (1) eels that were stocked from elvers imported from France or British Isles, (2) eels that were stocked at the yellow eel stage after being caught from the coastal waters of western Sweden, or (3) the natural (wild) eels which gradually migrated from the western coastal waters to the lakes on the eastern coast of Sweden.

The changes in Sr contents in the otolith of specimen No. 25110 were similar to those in Groups 2 and 3, which were caught from fresh water lakes of eastern Sweden and stocked from imported elvers. Because the Baltic Sea is semi-enclosed, the possibility that eel larvae drifted with Atlantic currents and recruited directly to the east coast of Sweden is very low. Nowadays glass eels are not recruited to the Baltic Sea, except in the most southwestern parts (Svärdson 1976) Most wild unstocked eels in the coastal waters of eastern Sweden must be from the west coast and must have migrated through brackish waters before entering fresh water lakes. If this were the case, the Sr contents in otolith No. 25110 should have several high Sr content bands as do the otoliths in Group 1 (Fig. 3) However, the $\mathrm{Sr} / \mathrm{Ca}$ ratio in this otolith drastically decreased at an early stage. Accordingly, eel No. 25110 seems to be best assigned to Case (1), which were released to fresh water at the elver stage after being imported from France or the British Isles.

Similarly, Nos. 25106 and 25108 are best assigned to Case (2), because the maps of Sr contents and the timeseries changes in $\mathrm{Sr}$ contents or $\mathrm{Sr} / \mathrm{Ca}$ ratios in them were similar to those of Group 4 (Figs. 3 \& 4), which were stocked into the fresh water lakes at the yellow eel stage after being collected from domestic brackish waters; or possibly Case (3), because the maps of $\mathrm{Sr}$ contents and the time-series change in $\mathrm{Sr} / \mathrm{Ca}$ ratios in otolith of the eels exhibited a similar geographic decline in salinity gradient from western to eastern coasts of Sweden. However Case (2) is most likely because the change in $\mathrm{Sr}$ contents or $\mathrm{Sr} / \mathrm{Ca}$ ratios was very rapid. To verify Case (3), it would be necessary to examine the Sr contents in otoliths of European eels around the coastal waters of Sweden

In conclusion, Sr X-ray maps and $\mathrm{Sr} / \mathrm{Ca}$ ratios of the atoliths were significantly different between eels col- 


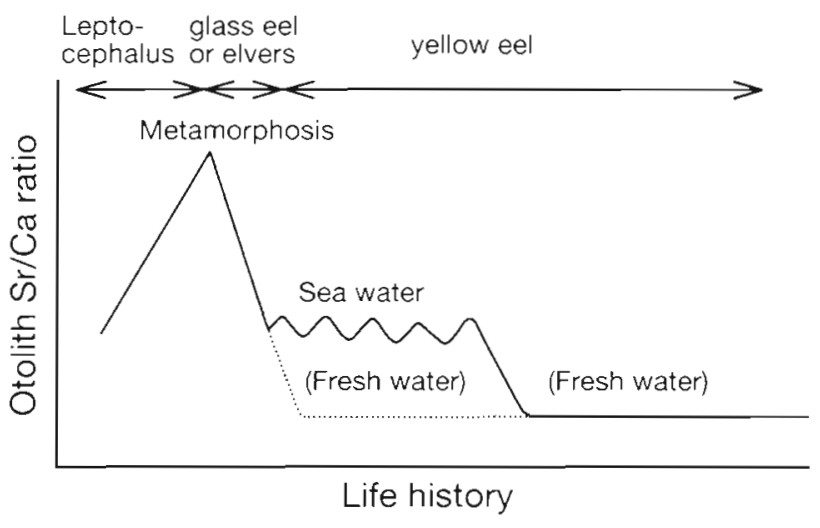

Fig. 5. Schematic diagram of the environmental history of the studied eel as indicated by the time series change of $\mathrm{Sr} / \mathrm{Ca}$ ratios in otoliths

lected from brackish and fresh water environments, and could be used as an environmental indicator to detect their migratory history between sea water and fresh water. A schematic diagram of the migratory history of the eels in this study is shown in Fig. 5.

Acknowledgements. This cooperative study was conducted with financial support from the National Science Council. Taiwan (Project No. NSC 84-2311-B-002-035 and 86-2311-B002-042). The authors are grateful to $\mathrm{Dr} \mathrm{H}$. Westerberg and the Swedish Meteorological and Hydrological Institute for supplying oceanographic data, Miss Y C. Tsai for preparing otolith specimens for WDX analysis, Miss C. E. Wu for typing the manuscript, and Dr R. W. Gauldie and 3 anonymous reviewers for reviewing the manuscript.

\section{LITERATURE CITED}

Bertin L (1.956) Eels-a biological study. Cleaver-Hume Press, London

Boetius J. Harding EF (1985) A re-examination of Johannes Schmidt's Atlantic eel investigations. Dana 4:129-162

Bruun AF (1963) The breeding of the north Atlantic freshwater eel. Adv Mar Biol 1:137-169

Casselman JM (1982) Chemical analyses of optically different zones in eel otoliths. In: Loftus $\mathrm{KH}$ (ed) Proceedings of the 1980 North American Eel Conference. Ontario Fish Tech Rep Ser 4, p 74-82

Castonguay M (1987) Growth of American and European eel leptocephali as revealed by otolith microstructure. Can J Zool 65:875-878

Erichsen L (1976) Statistik over alyngeluppsamling i svenska vattendrag. Inform Inst Freshwat Res, Drottningholm 8 $1-36$ (in Swedish)

Filuk J, Wiktor J (1988) Management of eel stocks in the Vistula and Szczecin lagoons in the light of the process of eel stocking. Biul Morsk Inst Ryb 5-6:36-44

Gauldie RW, Fournier DA, Dunlop DE, Coote G (1986) Atomic emission and microprobe studies of the ion content of otoliths of Chinook salmon aimed at recovering the temperature life history of individuals. Comp Biochem Physiol 84A(4):607-615

Hagström O, Wickström $H$ (1990) Immigration of young eels to the Skagerrak-Kattegatt area 1900 to 1989. Int Revue
Hydrobiol 75(6):707-716

Holmgren K, Wickström $H$ (1988) The quality of Swedish yellow eels used for stocking in $1987-$ a study of sex, size and wounds. Inform Inst Freshwat Res, Drottningholm 8 1-38 (in Swedish with English summary)

Kalish JM (1990) Use of otolith microchemistry to distinguish the progeny of sympatric anadromous and nonanadromous salmonids. Fish Bull US 88:657-666

Leopold $M$ (1976) Stocking as a main factor determining the level of eel catches in Poland. Int Counc Explor Sea (EIFAC) Symp Eel Res Mgmt 14:1-13

Limburg KE (1995) Otolith strontium trace environmental history of subyearling American shad Alosa sapidissima. Mar Ecol Prog Ser 119:25-35

McCleave JD, Kleckner RC (1985) Oceanic migrations of Atlantic eels (Anguilla spp.): adults and their offspring Contr Mar Sci 27(Suppl):316-337

McCleave JD, Kleckner RC, Castonguay M (1987) Reproductive sympatry of American and European eels and implications for migration and taxonomy. Am Fish Soc Symp $1: 286-297$

Nishizawa K (1978) Marine algae from a viewpoint of pharmaceutical studies. Jap J Phycol 26:73-78

Odum HT (1957) Biochemical deposition of strontium. Texas Univ Inst Mar Sci 4:39-114

Otake I, Ishii I, Nakahara M. Nakamura R (1994) Drastic changes in otolith strontium/calcium ratios in leptocephali and glass eels of Japanese eel Anguilla japonica. Mar Ecol Prog Ser 12:189-193

Pfeiler E (1984) Glycosaminoglycan breakdown during metamorphosis of larval bone fish Albula. Mar Biol Lett 5: $241-249$

Radtke RL (1984) Cod otoliths: information storage structures. In: Dahl E, Danielssen DS, Moksness E, Solendal P (eds) The propagation of cod Gadus morhua L. Flødevigen Rapp 1, p 273-298

Radtke RL (1989) Strontium-calcium concentration ratios in fish otoliths as environmental indicators. Comp Biochem Physiol 92(A):189-193

Radtke RL, Kinzie III RA, Folsom SD (1988) Age at recruitment of Hawaiian freshwater gobies. Environ Biol Fish 23: 205-213

Radtke RL, Townsend DW, Folson SD, Morrison MA (1990) Strontium:calcium concentration ratios in otoliths of herring larvae as indicators of environmental histories. Environ Biol Fish 27:51-61

Sadovy Y, Severin KP (1992) Trace element in biogenic aragonite: correlation of body growth rate and strontium levels in the otoliths of the white grunt, Haemulon plumieri (Pisces:Haemulidae). Bull Mar Sci 50:237-257

Sadovy Y, Severin KP (1994) Elemental patterns in red hind (Epinephelus guttatus) otoliths from Bermuda and Puerto Rico reflect growth rate, not temperature. Can J Fish Aquat Sci 51:133-141

Schmidt J (1925) The breeding places of the eel. Ann Rep Smithson Inst 1924:279-316

Secor DH (1992) Application of otolith microchemistry analysis to investigate anadromy in Chesapeake Bay striped bass Morone saxatilis. Fish Bull US 90:798-806

Sinha VRP, Jones JW (1967) On the age and growth of the freshwater eel (Anguilla anguilla). J Zool Soc Lond 153. 99-117

Svärdson G (1976) The decline of the Baltic eel population. Rep Inst Freshwat Res 55:136-143

Tesch FW (1983) Der Aal: Biologie und Fischerei, Vol. 2. Parey, Hamburg

Townsend DW, Radtke RL, Corewin S, Libby DA (1992) Stron- 
tium:calcium ratios in juvenile Atlantic herring Clupea harengus $\mathrm{L}$. otoliths as a function of water temperature. J Exp Mar Biol Ecol 160:131-140

Tzeng WN (1995) Migratory history recorded in otoliths of the Japanese eel, Anguilla japonica, elvers as revealed from SEM and WDS analyses. Zool Stud 34 (Suppl 1):234-236

Tzeng WN (1996) Effect of salinity and ontogenetic movement on Sr/Ca ratio in otolith of Japanese eel. J Exp Mar Biol Ecol 199:111-122

Tzeng WN, Tsai YC (1994) Changes in otolith microchemustry of the Japanese eel. Angulla japonica, during its migration from the ocean to the ruvers of Taiwan. J Fish Biol 45 $671-684$

This article was submitted to the editor
Tzeng WN, Wu HF, Wickström H (1995) Scannıng electron microscopic analysis of annulus microstructure in otolith of European eel, Anguilla anguilla. J Fish Biol 45:479-492

Westın L (1990) Orientation mechanısms in migrating European silver eel (Anguilla angulla): temperature and olfaction. Mar Biol 106:175-179

Wickström H (1984) The Swedish eel stocking programme EIFAC/FAO Techn Pap 42 (Suppl Vol. 1):68-83

Wickström H (1986) Growth of cultured eels stocked in two Swedish lakes. Vie Milieu 36:273-277

Williams KL (1987) An introduction to X-ray spectrometry $X$-ray fluorescence and electron mucroprobe analysis Allen \& Unwin, Boston

Manuscript first recerved: May 15, 1996

Revised version accepted: January 9, 1997 